\title{
THE FAULT IN OUR MOONS- THE EFFECT OF FESTIVALS AND PUBLIC HOLIDAYS IN THE INTRODUCTION OF ERROR IN RECALLED LMP DATES BY PREGNANT SUBJECTS UNDERGOING FIRST TRIMESTER SCAN
}

\author{
Rodriguez Mario Jose1, Sruthi Mankara Valson²
}

${ }^{1}$ Associate Professor, Department of Radiology, PK Das Institute of Medical Sciences, Ottapalam.

${ }^{2}$ Assistant Professor, Department of Community Medicine, PK Das Institute of Medical Sciences, Ottapalam.

\section{ABSTRACT}

\section{BACKGROUND}

An accurate estimation of gestational age is the cornerstone of decision making in obstetric practice. Dating by recalled last menstrual period is frequently inaccurate due to memory related sources of error. Ultrasound in the first trimester is an accepted method of accurately dating the duration of gestation.

\section{MATERIALS AND METHODS}

The study was designed as a cross-sectional study. First trimester patients undergoing a dating scan were assessed and gestational ages were obtained by recalled LMP and by ultrasound Crown-Rump Length (CRL). Subjects were grouped into a festival group if their LMP fell on a festival date and into a non-festival group if it did not. Differences between gestational age by recalled LMP and by ultrasound were analysed for both groups.

\section{RESULTS}

Out of 312 pregnant subjects, majority of 181 (58\%) belonged to 18 - 25 age group, 100 (32.1\%) belonged to 26 - 30 age group, 29 (9.3\%) belonged to 31 - 35 age group and remaining $2(0.6 \%)$ belonged to 36 - 40 age group. Out of 312 pregnant subjects, in 249 $(79.8 \%)$ of subjects LMP fell on normal days and in $63(20.2 \%)$ of pregnant subjects LMP fell on festival days. Out of total 63 mothers with festival LMP, majority $45(71.4 \%)$ of mothers belonged to 18 - 25 age group and in remaining mothers 16 (25.4\%) 2 (3.2\%) belonged to $26-30$ and $36-40$ age group respectively. This difference in age distribution among festival and non-festival LMP is statistically significant- P value of 0.03 . Out of total 63 mothers with festival LMP majority 35 (55.6\%) were multigravida and remaining 28 (44.4\%) were primigravida. This difference is statistically significant. P value $-<0.01$ the mean difference in gestational period among festival LMP group is $5.68+4.76$, higher than non-festival group $3.43+3.32$. This difference is statistically significant. P value- 0.001 .

\section{CONCLUSION}

Dating by recalled LMP shows systemic bias with statistically significant clustering of recalled LMP in proximity to public holidays and festivals in a study of first trimester patients undergoing a dating scan.

\section{KEYWORDS}

Dating ultrasound, Festivals, First Trimester, Gestational Age, Last Menstrual Period, LMP Recall Error.

HOW TO CITE THIS ARTICLE: Jose RM, Valson SM. The fault in our moons- the effect of festivals and public holidays in the introduction of error in recalled LMP dates by pregnant subjects undergoing first trimester scan. J. Evolution Med. Dent. Sci. 2017;6(73):5179-5182, DOI: 10.14260/Jemds/2017/1125

\section{BACKGROUND}

Anecdotal evidence exists to suggest that recalled LMPs fall on or in close proximity to easily recallable events such as festivals and national holidays. In a "festival-rich" environment like India with multiple religious, socio-cultural (for example- harvest related), state and central governmental holidays, it may be assumed that this may introduce errors in the recall of LMP dates. While previous studies have looked at recall errors in LMP,(1.2) none have overtly looked at the effects of festivals in generation of such

Financial or Other, Competing Interest: None.

Submission 16-08-2017, Peer Review 30-08-2017,

Acceptance 01-09-2017, Published 11-09-2017.

Corresponding Author:

Rodriguez Mario Jose,

Associate Professor,

Department of Radiology,

PK Das Institute of Medical Sciences,

Ottapalam- 682522, Kerala, India.

E-mail:mariojoserod@gmail.com

DOI: $10.14260 /$ jemds $/ 2017 / 1125$ error. In this study, we have evaluated first trimester patients coming for a dating ultrasound and compared gestational age by their recalled LMP date and by ultrasound scan.

\section{Aim and Objectives \\ MATERIALS AND METHODS \\ Study Design \\ Cross-sectional study.}

The study aims to look at whether festivals influence recalled LMP dates, and to quantify the degree of variability between the gestational age by LMP and by dating ultrasound.

\section{Study Period}

Patients with LMPs falling in a 1-year period from Jan 2015 Jan 2016.

\section{Study Subjects}

Pregnant subjects coming for first trimester dating scan. 


\section{Inclusion Criteria}

- Patients in the reproductive age group undergoing 1st trimester scan in a semi-urban setting in Kerala, India during a one-year period.

\section{Exclusion Criteria}

- Patients with irregular menstrual cycles.

- Patients who could not recall their LMP.

- Patients with multiple (twin or more) gestations on ultrasound.

- Patients with missed abortion or early embryonic death as their ultrasound diagnosis.

- Patients with recent pregnancy $(<9$ months since last childbirth).

\section{Sample Size Calculation}

From previous study on accuracy of recollection of LMP date,(1) only $56 \%$ of population were able to remember the exact LMP. Remaining $44 \%$ of patients had an approximate recalled LMP. Hence, $\mathrm{P}=44 \% \mathrm{Q}-100-\mathrm{P}=56 \%, \mathrm{~d}=20 \%$ of $\mathrm{P}$ Formulae used is $4 \mathrm{PQ} / \mathrm{d}^{2}$

$4 \times 44 \times 56 /(20 \% \times 44)^{2}=9856 /(8.8)^{2}=127$ Minimum sample size required is 127 .

\section{Sampling Method}

Consecutive sampling- total of 312 pregnant patients coming for dating scan in a one-year period were included.

\section{Study Procedure}

From each patient's data regarding age, parity index and LMP date was collected using a questionnaire. Gestational age based on LMP was calculated. First trimester ultrasonography was done for all pregnant subjects. Period of gestation based on USG was calculated from estimation of crown-rump length (CRL). Festival days during the year 2015 were determined and patients were classified into two groups, i.e. those pregnant women whose LMP fell on a festival or a national holiday "festival LMP group" and those pregnant women whose LMP fell on non-festival days "nonfestival LMP group." Difference in gestational period based on USG and LMP was noted. This difference in gestational period among festival and non-festival LMP groups were compared.

\section{Statistical Analysis}

Data was coded and entered in Microsoft Excel. The whole data was rechecked and analysed using statistical software SPSS version 16. The mean of difference in gestational period based on USG and LMP was calculated and compared among festival and non-festival LMP group using Mann-Whitney U test. The Pearson chi-square test was used to find out the association between other demographic variables and recall LMP dates. The level of significance was estimated with $95 \%$ confidence interval with $\mathrm{p}$ value of $<0.05$.

\section{RESULTS}

Out of 312 pregnant subjects, majority 181 (58\%) belonged to 18 - 25 age group, 100 (32.1\%) belonged to 26 - 30 age group, $29(9.3 \%)$ belonged to $31-35$ age group and remaining $2(0.6 \%)$ belonged to 36 - 40 age group, Figure 1 . The mean age was $25.13+4.17$. It ranged between 18 and 40 . Out of total pregnant subjects, 232 (74.4\%) were primigravida and 80 (25.6\%) were multigravida.

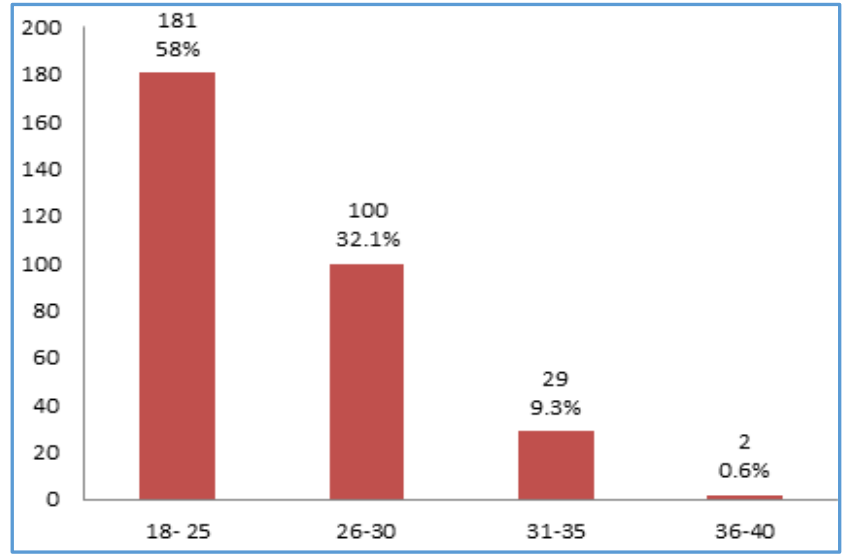

Figure 1. Age Distribution of Study Population

Out of 312 pregnant subjects, in 249 (79.8\%) of subjects LMP fell on normal days and in $63(20.2 \%)$ of pregnant subjects LMP fell on festival days.

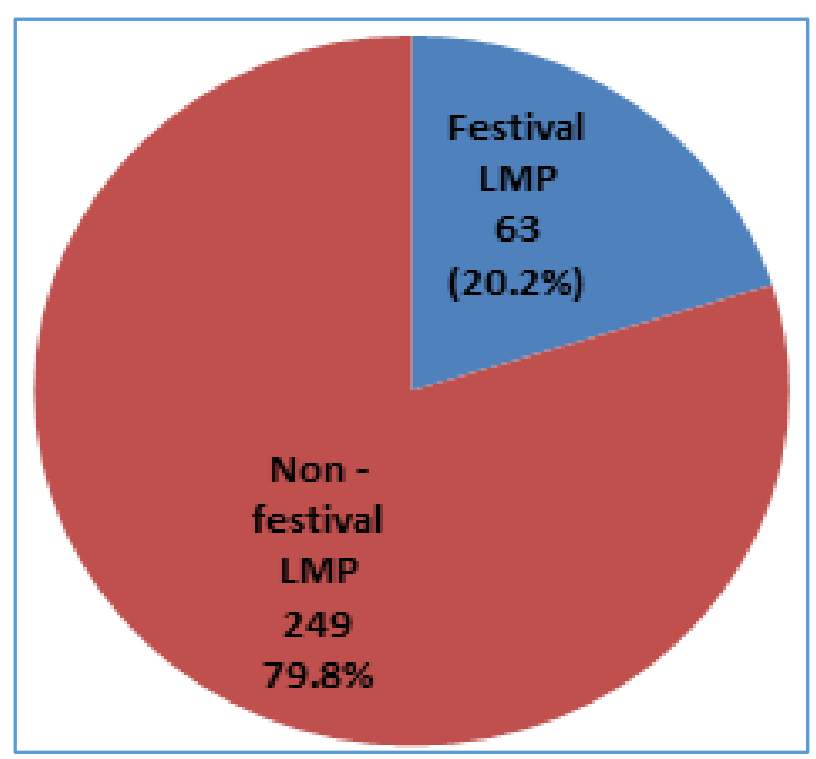

Figure 2. Distribution of Pregnant Mothers based on their Festival and Non-Festival LMP

\begin{tabular}{|c|c|c|c|c|c|}
\hline \multirow[b]{2}{*}{$\begin{array}{l}\text { Age } \\
\text { Group }\end{array}$} & \multicolumn{2}{|c|}{ LMP Date } & \multirow[b]{2}{*}{ Total } & \multirow[b]{2}{*}{$\begin{array}{c}\text { Statistical } \\
\text { Signifi- } \\
\text { cance }\end{array}$} & \multirow[b]{2}{*}{$\begin{array}{c}P \\
\text { value }\end{array}$} \\
\hline & $\begin{array}{c}\text { Non- } \\
\text { Festival } \\
\text { LMP }\end{array}$ & $\begin{array}{c}\text { Festival } \\
\text { LMP }\end{array}$ & & & \\
\hline $18-25$ & $\begin{array}{c}136 \\
54.6 \% \\
\end{array}$ & $\begin{array}{c}45 \\
71.4 \% \\
\end{array}$ & 181 & \multirow{5}{*}{$\begin{array}{l}\text { Fisher's } \\
\text { exact value } \\
-8.404\end{array}$} & \multirow{5}{*}{0.03} \\
\hline $26-30$ & $\begin{array}{c}84 \\
33.7 \%\end{array}$ & $\begin{array}{c}16 \\
25.4 \%\end{array}$ & 100 & & \\
\hline $31-35$ & $\begin{array}{c}27 \\
10.8 \% \\
\end{array}$ & $\begin{array}{c}2 \\
3.2 \% \\
\end{array}$ & 29 & & \\
\hline $36-40$ & $\begin{array}{c}2 \\
0.8\end{array}$ & 0 & 2 & & \\
\hline Total & 249 & 63 & 312 & & \\
\hline
\end{tabular}

Out of total 63 mothers with festival LMP, majority $45(71.4 \%)$ of mothers belonged to 18 - 25 age group and remaining mothers $16(25.4 \%), 2(3.2 \%)$ belonged to $26-30$ and $36-40$ age group respectively. This difference in age 
distribution among festival and non-festival LMP is statistically significant- $P$ value of 0.03 .

\begin{tabular}{|c|c|c|c|c|c|}
\hline \multirow[b]{2}{*}{ Parity } & \multicolumn{2}{|c|}{ LMP Date } & \multirow[b]{2}{*}{ Total } & \multirow[b]{2}{*}{$\begin{array}{c}\text { Statistical } \\
\text { Signi- } \\
\text { ficance }\end{array}$} & \multirow[b]{2}{*}{$\begin{array}{c}P \\
\text { value }\end{array}$} \\
\hline & \begin{tabular}{|c|} 
Non- \\
Festival \\
LMP
\end{tabular} & $\begin{array}{c}\text { Festival } \\
\text { LMP }\end{array}$ & & & \\
\hline Primigravida & $\begin{array}{c}204 \\
81.9 \% \\
\end{array}$ & $\begin{array}{c}28 \\
44.4 \%\end{array}$ & 232 & \multirow{3}{*}{$\begin{array}{c}\text { Chi-square } \\
\text { value } \\
37.05\end{array}$} & \multirow{3}{*}{$<0.001$} \\
\hline Multigravida & $\begin{array}{c}45 \\
18.1 \%\end{array}$ & $\begin{array}{c}35 \\
55.6 \%\end{array}$ & 80 & & \\
\hline Total & 249 & 63 & 312 & & \\
\hline
\end{tabular}

Out of total 63 mothers with festival LMP, majority 35 (55.6\%) were multigravida and remaining 28 (44.4\%) were primigravida. This difference is statistically significant, $\mathrm{P}$ value of $<0.01$.

\begin{tabular}{|c|c|c|c|}
\hline Group & $\begin{array}{c}\text { Mean } \pm \text { St. Deviation } \\
\text { Difference in } \\
\text { Gestational Period }\end{array}$ & $\begin{array}{c}\text { Statistical } \\
\text { Significance }\end{array}$ & $\begin{array}{c}P \\
\text { value }\end{array}$ \\
\hline Festival LMP & $5.68 \pm 4.76$ & \multirow{2}{*}{$\begin{array}{c}\text { Mann } \\
\text { Whitney U } \\
\text { test } \\
\text { (U value) } \\
5.67\end{array}$} & \multirow{2}{*}{0.001} \\
\hline $\begin{array}{l}\text { Non-festival } \\
\text { LMP }\end{array}$ & $3.43 \pm 3.32$ & & \\
\hline \multicolumn{4}{|c|}{$\begin{array}{c}\text { Table 3. Comparison of Difference in Gestational Period } \\
\text { among Festival and Non-Festival LMP Group }\end{array}$} \\
\hline
\end{tabular}

The mean of difference in gestational period among festival LMP group is $5.68 \pm 4.76$ is higher than non-festival group of $3.43 \pm 3.32$. This difference is statistically significant. $P$ value -0.001 .

\section{DISCUSSION}

The determination of gestational age is important for both the mother, who wants to know when to expect the birth of her baby as well as for her obstetrician so that he or she may choose the times at which to perform various screening tests and assessments such as nuchal translucency screening, assessment of foetal maturity and induction of labour for post-dated pregnancies.

Gestational age has traditionally been determined from the date of the last menstrual period. This assumes that conception occurs on day 14 of the cycle. However, ovulation varies greatly in relation to the menstrual cycle, both from cycle to cycle and individual to individual. Basing gestational age on the last menstrual period, date tends to result in an overestimation.

A number of studies have examined the role of the dating scan in obstetric decision making.(3.4,5) The first trimester dating scan is widely held to be a reliable indicator of the period of gestation.(6,7) A study by Taipale and Hiilesma( ${ }^{(7)}$ showed that ultrasound is more accurate than last menstrual period date in dating, and when it was used as the prime determinant of gestational age the number of post-term pregnancies reduced.

Hoffman et al identified certain subsets of population where inaccuracies in ultrasound derived gestational age was present, viz. non-Hispanic Black, Hispanic women and women of non-optimal body weight.(3) No studies exist showing inaccuracies in scan derived gestational ages in Asian populations.

In as much as proximity to a festival date introduces recall error, obstetricians should be aware of such bias and keep first trimester scan derived dates as the primary source for estimating the duration of pregnancy.

Festival dates were taken in accordance with the published list of government and state holidays for the year 2015 in the Kerala State Government Gazette( ${ }^{(8)}$ Scrutiny of the list reveals that a total of 21 public holiday during the calendar year 2015 .

Two seemingly contradictory conclusions, the study arrived at were the relative increase in multigravida showing festival associated recalled LMP and a similar observation in younger primigravida.

It is likely that domestic pressures of managing a larger household leave the older mothers less aware of a seemingly less important event that is her last menstrual period date.

The younger primigravida is also prone to date recall error and conversely older subjects in the cohort, especially older nullipara are more conscious of their exact LMP date. This may be a consequence of greater patient education in older nulliparous subjects and more anxiety towards infertility related issues.

Our study shows that it is probable that proximity of a festival may introduce bias into the recall of LMP dates in our patient population. It is possible that this represents a form of memory recall error termed as time-slice error.

Time-slice errors occur when a correct event is in fact recalled; however, the timing of the event that was asked to be recalled does not correspond the one that is recalled. In other words, the timing of events is incorrectly remembered. As described in a paper by Hyman Jr. IE and Loftus EF, often the event or event details that are recalled occurred within a short time proximity to the memory required to be recalled.(9)

Inaccuracies in gestational age assessment has been shown to be linked with an increase in adverse late pregnancy outcomes.

The study demonstrates the efficacy of the dating scan in avoidance of errors in estimation of gestational age. It highlights the importance of making the first trimester dating scan readily available, especially in a country with a predominantly agrarian population such as India.

\section{CONCLUSION}

Statistically significant differences $(p$ values $<0.05)$ were found between Festival group and the Non-festival group for difference in period of gestation when derived by ultrasound dating as opposed to recalled LMP method. Multigravida tended to have more recalled LMP corresponding to festival dates. However, it was noted that younger patients were more likely to give a recalled LMP corresponding to a festival date.

\section{REFERENCES}

[1] Wegienka G, Baird DD. A comparison of recalled date of last menstrual period with prospectively recorded dates. J Women's Health (Larchmit) 2005;14(3):24852. 
[2] Gernand AD, Paul RR, Ullah B, et al. A home calendar and recall method of last menstrual period for estimating gestational age in rural Bangladesh: a validation study. J Health Popul Nutr 2016;35(1):34.

[3] Hoffman CS, Messer LC, Mendola P, et al. Comparison of gestational age at birth based on last menstrual period and ultrasound during the first trimester. Paediatr Perinat Epidemiol 2008;22(6):587-96.

[4] Morin I, Morin L, Zhang X, et al. Determinants and consequences of discrepancies in menstrual and ultrasonographic gestational age estimates. BJOG 2005;112(2):145-52.

[5] Thorsell M, Kaijser M, Almström H, et al. Expected day of delivery from ultrasound dating versus last menstrual period-obstetric outcome when dates mismatch. BJOG 2008;115(5):585-9.
[6] Doubilet PM. Should a first trimester dating scan be routine for all pregnancies? Semin Perinatol 2013;37(5):307-9.

[7] Taipale P, Hiilesmaa V. Predicting delivery date by ultrasound and last menstrual period in early gestation. Obstet Gynaecol 2001;97(2):189-94.

[8] Kerala Public Holiday List 2015 Government Of Kerala General Administration (Co-ordination) Department NOTIFICATION G.O.(P) No.305/2014/ GAD Dated, Thiruvananthapuram, 31-10-2014.

[9] Hyman IE, Loftus EF. Errors in autobiographical memory. Clin Psychol Rev 1998;18(8):933-47. 